\title{
Resolution of the Spectroscopy vs. Crystallography issue for NO intermediates of Nitrite Reductase from Rhodobacter sphaeroides
}

\author{
Somdatta Ghosh ${ }^{\dagger}$, Abhishek Dey ${ }^{\dagger}$, Oleg M. Usov $\ddagger$, Yan Sun ${ }^{\ddagger}$, Vladimir M. Grigoryants ${ }^{\ddagger}$, \\ Charles P Scholes ${ }^{\star}, \ddagger$, and Edward I. Solomon. ${ }^{*} \dagger$ \\ Department of Chemistry, Stanford University, Stanford, California 94305, Department of \\ Chemistry, University at Albany, State University of New York, Albany, New York 12222
}

Copper nitrite reductase $(\mathrm{NiR})$ is a homotrimeric enzyme, containing a $\mathrm{T} 1$ copper site, which transfers electrons to the $\mathrm{T} 2$ catalytic site, where nitrite is reduced by one electron to nitric oxide $\left(\mathrm{NO}_{2}^{-}+2 \mathrm{H}^{+}+\mathrm{e}^{-} \rightarrow \mathrm{NO}+\mathrm{H}_{2} \mathrm{O}\right) .{ }^{1-3}$ Recently a side-on bound copper nitrosyl complex of NiR has been crystallized by reacting the reduced enzyme with excess NO. ${ }^{4}$ Based on the EPR spectrum of the species generated by the reaction of reduced $\mathrm{NiR}$ with saturated $\mathrm{NO}$ in solution, it has been assigned as an $\eta^{2}-\mathrm{NO}^{-} \mathrm{Cu}^{2+}$ species. However, spectroscopic data on several $\mathrm{Cu}$-nitrosyl model complexes ${ }^{5}$ and an $\mathrm{NO}$ adduct formed by reacting reduced $\mathrm{NiR}$ with nitrite $^{6}$ and DFT calculations on an $\eta^{2}-\mathrm{NOCu}$ species ${ }^{7}$ describe these complexes as $\mathrm{Cu}^{+} \mathrm{NO}$. In this study, we define the species generated in solution by reacting reduced NiR with NO, using EPR, MCD and ENDOR spectroscopy and correlate these with that observed by crystallography.

Reduced NiR reacted with saturated NO solution generates the EPR spectrum in Figure 1A red, which is equivalent to the spectrum reported by Tocheva et al. ${ }^{4}$ This species has an EPR signal characteristic of an oxidized $\mathrm{T} 2 \mathrm{Cu}\left(\mathrm{g}_{\|}=2.30\right.$ and $\left.\mathrm{A}_{\|}=117 \mathrm{G}\right)$. The MCD spectrum (Fig. 1B, red) has low energy d-d bands, also indicative of a T2 cupric complex. Both EPR and MCD spectra show a negligible T1 contribution indicating that this site is reduced (Fig. S1).

Nitrite binds to the T2 site of the resting WT enzyme, ${ }^{8,9}$ but the EPR and, in particular, the MCD features of the nitrite bound T2 site are obscured by the dominant T1 Cu signals. However under these conditions (nitrite bound), the $\mathrm{T} 1 \mathrm{Cu}$ could be selectively reduced with acsorbate. The EPR spectrum of the nitrite bound T2 species (Fig. 1A, blue) is identical to that produced above by reacting reduced NiR with excess NO. The MCD spectrum (Fig. 1B, blue) of the T1 reduced T2-nitrite bound form is also identical to that generated by the reduced enzyme with NO. The T2 EPR spectrum and the MCD d-d bands of the resting WT enzyme are very sensitive to nitrite binding (Fig. S1C, D). Thus the EPR and MCD data strongly indicate that the species generated by the reaction of excess $\mathrm{NO}$ with reduced $\mathrm{NiR}$ has $\mathrm{T} 1$ reduced and $\mathrm{T} 2$ oxidized with nitrite bound.

Further $\mathrm{N}^{14}$ and $\mathrm{H}^{1}$ ENDOR data for this species generated by the reaction of reduced NiR with an NO solution (Fig. 1C, D, red) and those for a form with T1+T2 oxidized and nitrite bound (collected at $\mathrm{g}=2.266$ where there is no contribution from T1, Fig. 1C, D, blue) have the same features. The nitrogen features (Fig. 1C) from $\mathrm{Cu}^{2+} \mathrm{NO}_{2}{ }^{-}$bound $\mathrm{T} 2$ are from its histidines, and these features all show lower ENDOR frequencies and smaller hyperfine couplings due to the change of the $\mathrm{T} 2$ axial ligand from aquo to nitrite. ${ }^{10}$

\footnotetext{
*To whom all correspondence should be addressed Edward.Solomon@stanford.edu, cps14@albany.edu

$\dagger$ Department of Chemistry, Stanford University, CA

\$Department of Chemistry, State University of New York, Albany
} 
From the above results the reaction of reduced NiR with excess NO gives $\mathrm{T} 1$ reduced $\mathrm{T} 2$ $\mathrm{Cu}^{2+} \mathrm{NO}_{2}{ }^{-}$. However, the reaction of the reduced enzyme with limited $\mathrm{NO}$ has an EPR signal (Fig. 2A, green), characteristic of a $\mathrm{Cu}^{+} \mathrm{NO}^{*}$ species. ${ }^{6}$ This species lacks $\mathrm{d}-\mathrm{d}$ bands in the MCD spectrum (Fig. S3), further confirming that the $\mathrm{Cu}$ is reduced. Therefore, reduced NiR forms $\mathrm{a} \mathrm{Cu}^{+} \mathrm{NO}^{\circ}$ species at low concentrations of NO.

The reaction of reduced $\mathrm{NiR}$ with excess $\mathrm{NO}$ involves two one-electron oxidations; reduced $\mathrm{T} 2 \rightarrow$ oxidized $\mathrm{T} 2$, and $\mathrm{NO} \rightarrow \mathrm{NO}_{2}^{-}$. A similar reaction has been observed for the coupled binuclear $\mathrm{Cu}$ active sites in hemocyanins ${ }^{11}$ (Scheme $\left.\mathrm{S} 1\right)$. Deoxyhemocyanin $\left(2 \mathrm{Cu}^{+}\right)$reacts with $\mathrm{NO}$ generating $\mathrm{N}_{2} \mathrm{O}$, and a met $\left(2 \mathrm{Cu}^{2+}\right)$ form, which further reacts with $\mathrm{NO}$ to generate the half-met $\left(\mathrm{Cu}^{2+} \mathrm{Cu}^{+}\right)$nitrite bound form. $\mathrm{N}_{2} \mathrm{O}$ evolution is in fact detected during the reaction of reduced NiR with excess $\mathrm{NO}$, using nitrous oxide reductase $\left(35 \mu\right.$ mols $\mathrm{N}_{2} \mathrm{O}$ reduced $\min ^{-1} \mathrm{mg}^{-1}$ of enzyme), which requires $\mathrm{N}_{2} \mathrm{O}$ as its substrate. ${ }^{12}$ Reaction of the resting WT NiR (analogous to the met form of hemocyanin) with NO generates the T1 reduced, T2 oxidized form of the enzyme $\left(g_{\|}=2.30, A_{\|}=150 G\right)$, which converts to the nitrite bound $\mathrm{T} 2$ form (Fig. $2 \mathrm{~B}, \mathrm{D} \rightarrow \mathrm{F} \rightarrow \mathrm{G}$, Scheme 1), indicating NO is oxidized to nitrite and nitrite binding is slow.

To evaluate the entire reaction mechanism, reduced $\mathrm{NiR}$ was reacted with limited $\mathrm{NO}$ solutions and intermediates were trapped at different times. We were able to trap the $\mathrm{Cu}^{+} \mathrm{NO}{ }^{*}$ form at shorter times, leading to the formation of the $\mathrm{T} 1$ reduced, $\mathrm{T} 2$ oxidized form, and ultimately generating the T1 reduced, T2 oxidized nitrite bound form (Fig. 2A, Scheme $1 \mathrm{~A} \rightarrow \mathrm{B} \rightarrow \mathrm{F}$ $\rightarrow \mathrm{G}$ ) at longer times. A reaction mechanism consistent with these results is presented in Scheme 1. Note that in the scheme, intermediate E is not observed because of rapid ET from $\mathrm{T} 2 \rightarrow \mathrm{T} 1 .^{13}$ The experimental details and kinetic rates are provided in the supporting information.

There is still one issue to resolve on correlating the spectroscopy with crystallography. The $\mathrm{Cu}-\mathrm{NO}$ species trapped in the crystal structure has a side-on conformation. ${ }^{4}$ DFT calculations indicate that this species is best described as a $\mathrm{Cu}^{+}-\mathrm{NO}^{\circ}$ species. ${ }^{7}$ However an end-on $\mathrm{Cu}-\mathrm{NO}$ species is also trapped after limited exposure to $\mathrm{NO}$ gas (B, in scheme 1) which is equivalent to the species generated by reacting reduced $\mathrm{NiR}$ with nitrite $\left(\eta^{1}-\mathrm{CuNO}\right){ }^{6}$ Geometry optimized DFT calculations (B3LYP/6-311g* on Cu, N, O and 6-31g* on C, H) ${ }^{14}$ of both side-on (Fig. 3 , red) and end-on (Fig. 3, blue) $\mathrm{Cu}-\mathrm{NO}$ adducts indicate that both forms have a $\mathrm{Cu}^{+} \mathrm{NO}^{\circ}$ electronic configuration and that the end-on structure is more stable by $7 \mathrm{kcal} / \mathrm{mol}$. However the orientation of the $2^{\text {nd }}$ sphere aspartic acid residue (Asp129) 9,15 appears to play a key role in determining the geometry of the $\mathrm{Cu}-\mathrm{NO}$ species. In the side-on adduct this residue is perpendicular to the $\mathrm{Cu}-\mathrm{N}-\mathrm{O}$ plane and $\mathrm{H}$-bonds to the $\mathrm{O}$ of $\mathrm{N}-\mathrm{O}$ (Fig. 3 red) while in the endon structure the Asp129 residue $\mathrm{H}$-bonds to the $\mathrm{O}$ of $\mathrm{NO}$ and is parallel to the $\mathrm{Cu}-\mathrm{N}-\mathrm{O}$ plane (Fig. 3 blue). Both orientations of the Asp129 residue have been observed in crystal structures. 15 The Asp129 residue exists in the perpendicular orientation in the crystal structures of the oxidized and reduced $\mathrm{NiR}$ and $\mathrm{H}$-bonds to the axial ligand. However, to form the more stable end-on $\mathrm{Cu}^{+} \mathrm{NO}^{\circ}$ adduct this aspartate residue has to rotate $90^{\circ}$ which can occur in solution but may not be feasible in a crystal.

In summary, the species generated in solution during the reaction of reduced $\mathrm{NiR}$ with excess $\mathrm{NO}$ is the $\mathrm{T} 1$ reduced, $\mathrm{T} 2$ oxidized nitrite bound form and not the side-on $\mathrm{Cu}-\mathrm{NO}$ species observed in the crystal structure. The latter is best described as $\mathrm{Cu}^{+} \mathrm{NO}^{*}$ rather than $\mathrm{Cu}^{2+} \mathrm{NO}^{-}$. The mechanism for the reaction of reduced NiR with excess NO involves its two electron oxidation, generating $\mathrm{N}_{2} \mathrm{O}$. This oxidized form of the enzyme oxidizes $\mathrm{NO}$ generating nitrite bound to the oxidized $\mathrm{T} 2$ site generated by ET from $\mathrm{T} 2 \rightarrow \mathrm{T} 1$. DFT calculations provide insight into factors which favor the $\eta^{2}-\mathrm{NO}^{\circ} \mathrm{Cu}^{+}$complex in the crystal structure. 


\section{Supplementary Material}

Refer to Web version on PubMed Central for supplementary material.

\section{Acknowledgements}

This research is supported by NIH DK- 31450 (E.I.S), NIH EB00326929 (C.P.S).

\section{References}

1. Godden JW, Turley S, Teller C, Adman ET, Liu MY, Payne WJ, LeGall PJ. Sci 1991;253:438.

2. Murphy MEP, Turley S, Adman ET. J Biol Chem 1997;272:28455. [PubMed: 9353305]

3. Suzuki S, Kataoka K, Yamaguchi K. Acc Chem Res 2000;33:728. [PubMed: 11041837]

4. Tocheva EI, Rosell FI, Mauk AG, Murphy ME. Sci 2004;304:867.

5. Ruggiero CE, Carrier SM, Antholine WE, Whittaker JW, Cramer CJ, Tolman WB. J Am Chem Soc 1993;115:11285.

6. Usov OM, Sun Y, Grigoryants VM, Shapleigh JP, Scholes CP. J Am Chem Soc 2006;128:13102. [PubMed: 17017790]

7. Wasbotten IH, Ghosh A. J Am Chem Soc 2005;127:15384. [PubMed: 16262398]

8. Strange RW, Murphy LM, Dodd FE, Abraham ZHL, Eady RR, Smith BE, Hasnain SS. J Mol Biol 1999;287:1001. [PubMed: 10222206]

9. Zhao Y, Lukoyanov DA, Toropov YV, Wu K, Shapleigh JP, Scholes CP. Biochem 2002;41:7464. [PubMed: 12044180]

10. Veselov A, Olesen K, Sienkiewicz A, Shapleigh JP, Scholes CP. Biochem 1998;37:6095. [PubMed: 9558348]

11. Solomon, EI. Ch 2. In: Spiro, TJ., editor. Copper Proteins. Acad. Press; NY: 1981.

12. There exist micro-organisms with a truncated denitrification chain catalyzing the reduction of $\mathrm{NO}_{2}{ }^{-}$to NO." This mechanism suggests that in the presence of excess NO, NiR may also be used to reduce NO to $\mathrm{N}_{2} \mathrm{O}$. ${ }^{\#}$ Casella S, Shapleigh JP, Toffanin A, Basaglia M. Biochem Soc Trans 2006;34:130. [PubMed: 16417501]

13. Farver O, Eady RR, Abraham ZHL, Pecht I. Febs Lett 1998;436:239. [PubMed: 9781686]

14. Frisch, MJ., et al., editors. Gaussian 03, Revision C. 02. Full Reference in SI

15. Antonyuk SV, Strange RW, Sawers G, Eady RR, Hasnain SS. Proc Natl Acad Sci 2005;34:12041. [PubMed: 16093314] 

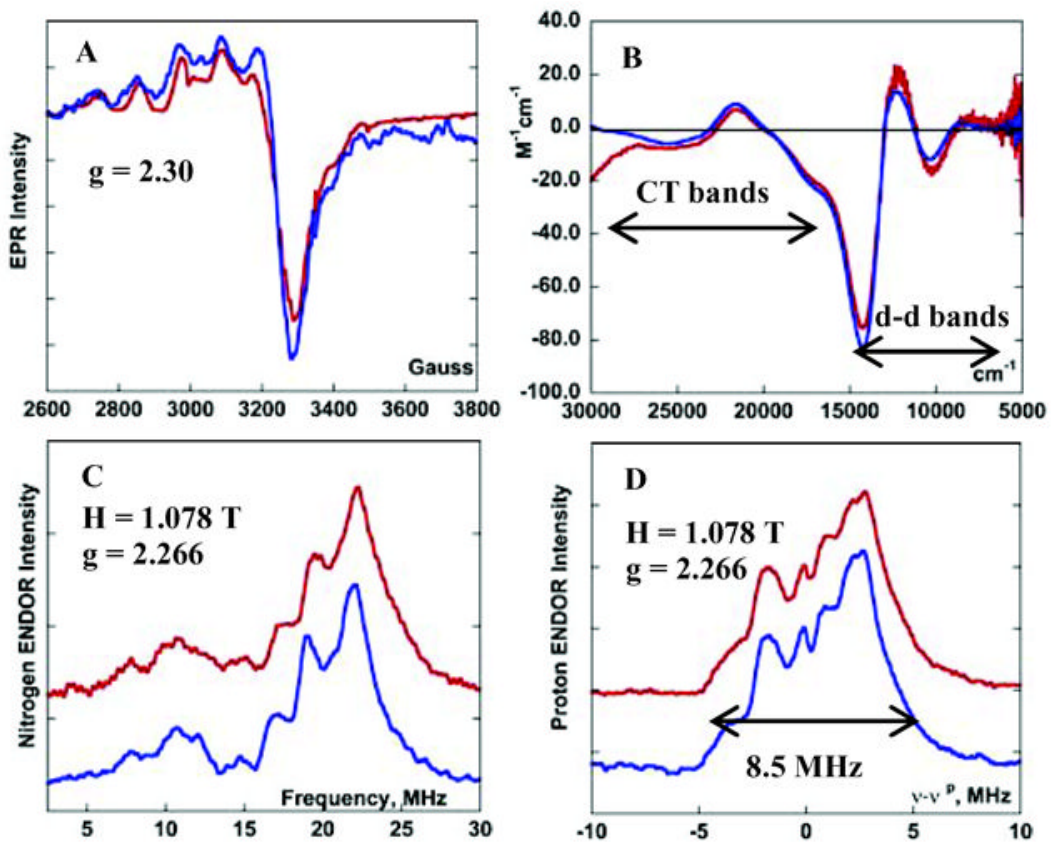

Figure 1.

Overlay of reduced NiR with excess NO (red) and nitrite bound NiR (blue) A) EPR B) MCD, C) $\mathrm{N}^{14}$ ENDOR, D) $\mathrm{H}^{1}$ ENDOR, with exchangeable features with $8.5 \mathrm{MHz}$ coupling. Parts $\mathrm{A}$ and $\mathrm{B}$ have nitrite bound to $\mathrm{T} 2$ site with the $\mathrm{T} 1 \mathrm{Cu}$ reduced to remove intense overlaying $\mathrm{T} 1$ features. ENDOR data are collected at 1.078T where there is no contribution from $\mathrm{T} 1 \mathrm{Cu}$. 

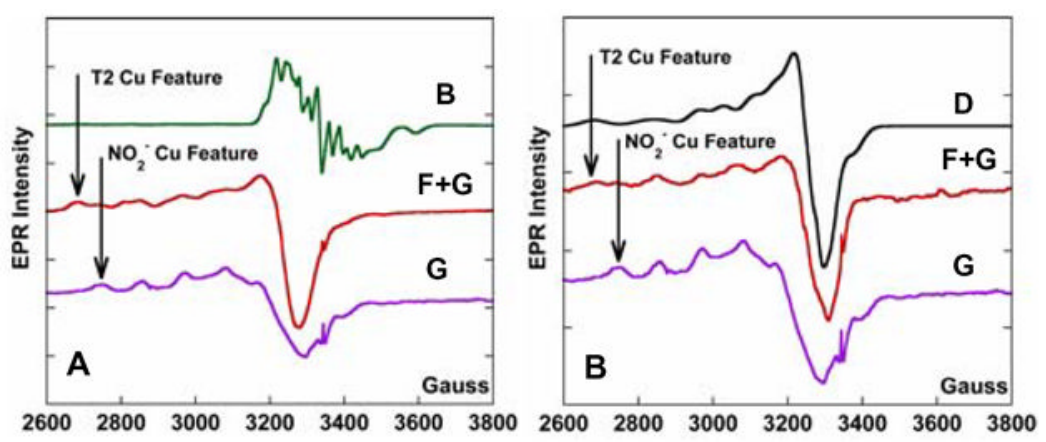

Figure 2.

EPR spectra A) following the reaction of reduced NiR with sub-stoichiometric NO solution (10:1 enzyme: NO) trapped at 1 second (green) 4 second (red) and 18 seconds (purple). B) following the reaction of the resting oxidized enzyme (black) with NO gas at 4 seconds (red) and 90 seconds (purple). Letters correspond to Scheme 1. 


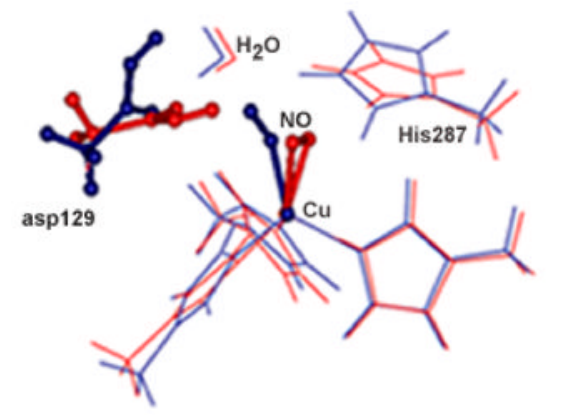

$\begin{array}{lcc} & \text { side-on } & \text { end-on } \\ \text { Cu-N (NO) } & 1.91 & 1.83 \\ \text { Cu-O (NO) } & 2.04 & 2.75 \\ \text { Cu-N } & 1.95 & 1.98 \\ \text { Cu-N } & 2.01 & 2.07 \\ \text { Cu-N } & 2.21 & 2.11 \\ \text { N-O } & 1.22 & 1.18 \\ \text { Cu-N-O } & 75 & 131\end{array}$

Figure 3.

Overlay of the DFT optimized side-on bound NO (red) and end-on bound NO (blue) structures indicating the different orientations of the aspartate residue. 


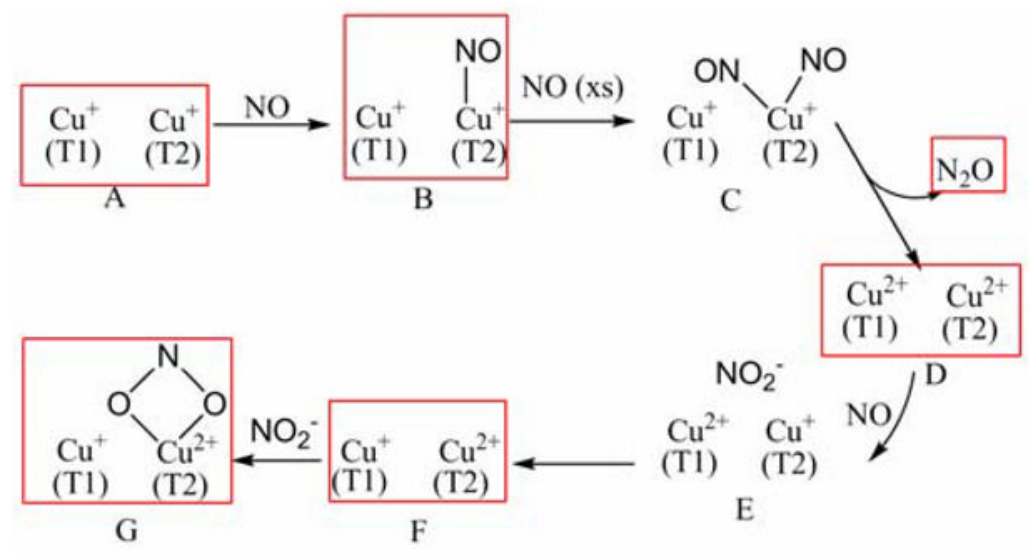

Scheme 1.

Proposed mechanism for the formation of nitrite bound T2 NiR from reduced enzyme with excess NO. Red boxes $=$ species observed. 